\title{
Synergy of the Pentahelix Model to Establish Resilient Smes in Facing New Normal during Covid-19 Pandemic
}

\author{
Herdiana Dyah Susanti ${ }^{1}$, Dian Arief Pradana ${ }^{2}$, Endang Suprihatin ${ }^{3}$ \\ ${ }^{1,3}$ Faculty of Engineering, Universitas 17 Agustus 1945 Banyuwangi, Indonesia \\ 2Faculty of Teacher Training and Education, University of 17 Agustus 1945 Banyuwangi, Indonesia \\ herdianadyahs@gmail.com,dianariefpradana.dap@gmail.com,endangwangi@gmail.com
}

\begin{abstract}
Coronavirus new which caused the outbreak of pneumonia and caused the closure of tourist destinations and caused many SMEs products to be returned by the souvenir center and SMEs production stopped during the Covid-19 pandemic. Banyuwangi Regency has also experienced the closure of tourist destinations starting March 2020 and has an impact on SMEs in Banyuwangi Regency, one of which is Ratu Manis SMEs. After the closure of tourist attractions, $70 \%$ of Ratu Manis SMEs products that were entrusted to the souvenir center and tourist attractions were returned. The number of SMEs Ratu Manis production has also decreased. Many exhibition events at every festival held in Banyuwangi Regency have been canceled due to the Covid-19 pandemic. Ratu Manis SMEs is trying to rise from the impact caused by the Covid-19 pandemic through synergy from various parties with the help of the government, academics, media and the community using the pentahelix approach. The research approach used in this research is descriptive research. The data sources used in this study are secondary and primary data sources. The data were collected using data collection techniques, namely observation and interviews with the source triangulation strategy for data validity. With penta helix synergy of industry, government, academia, media and the community sweet queen SMEs can survive to face the pandemic covid-19 and may even improve the quality of the products and sales turnover also increased from 20 $\mathrm{kg}$ to $40 \mathrm{~kg}$ per day.
\end{abstract}

Keywords

SMEs, Penta helix, new normal; covid-19

\section{Introduction}

Currently all companies are trying to increase their competitiveness. To achieve this, a sustainable concept is needed, for example from an environmental, social and economic side which is the impact of the development of science and innovation from various multidisciplinary institutions (Correia, 2019, Hicks et.al, 2016). In the traditional way, the process of maintaining sustainability is carried out using closed innovations that only use internal company considerations while ignoring ideas outside the company. Closed innovation to achieve sustainable competitiveness requires a lot of resources including employees (Leminen, 2015). The development of closed innovation must consider various parameters such as capital, social, intellectual and natural resources to create sustainable competitiveness (Vyakina, 2018). The concept of sustainable competitiveness is different from the conventional competitiveness concept which is only used for the short term (Mathur, 2017) 
The concept of closed innovation is very difficult to apply in Micro, Small and Medium Enterprises (SMEs). A suitable model to support sustainable competitiveness in SMEs is an open innovation concept that requires synergy between companies and stakeholders (Vanhaverbeke, 2013), for example by using the penta helix model (Leydesforff, 2016). The penta helix model is a synergy of five stakeholders, namely academia, business, government, media, and the community. To realize innovation, the triple helix strategy has evolved into a penta helix strategy with various elements of society and non-profit organizations involved. Through synergistic interactions, it is hoped that innovations will emerge supported by the collaboration of various resources (Lindmark, Sturesson \& Roos, 2009).

Academics are a source of knowledge that has concepts and theories so that businesses gain an increased and prolonged competitive advantage. Business is an entity that has the activity of digesting objects or services to be valuable. The government is one of the stakeholders who has regulations and responsibilities in developing business. Meanwhile, the media are stakeholders who have more information to grow the business and play a strong role in promoting the business. Communities are people who have the same attention and are relevant to the business being raised. Ansari (2019) stated that Business Judgment Rule basically adheres to the principle that a company's directors cannot be held accountable for losses arising from a decision-making action, as long as the directors in making these decisions have been based on good intentions and are entirely in the interest company.

One of the SMEs that requires an open innovation concept through the penta helix model is the Ratu Manis SMEs, which is one of the SMEs in Banyuwangi Regency which produces various kinds of typical Banyuwangi souvenirs. Ratu Manis SMEs produces dumplings for laughter, ladrang tempong. salted egg ladrang, and chocolate klemben. In marketing Ratu Manis SMEs is carried out on a consignment system in gift shops in Banyuwangi, Surabaya, Malang, and Bali Regencies. However, in March 2020, all tourism businesses were affected by the Corona-19 pandemic caused by the 2019 Coronavirus which was named by the World Health Organization (WHO) which was reported to have first occurred in the city of Wuhan. Coronavirus 2019 is transmitted through droplets and contact with droplets which can cause respiratory tract infections and if acute respiratory distress syndrome (ARDS) the prognosis is poor, especially if it is accompanied by comorbidities, advanced age and previously had a history of lung disease (Handayani et al., 2020).

The closure of tourism throughout Indonesia has an impact on Ratu Manis SMEs, 70 $\%$ of products that have been entrusted to souvenir shops are returned because they have expired, causing many losses to Ratu Manis SMEs. In April 2020, Ratu Manis SMEs, assisted by the University of 17 August 1945, Banyuwangi, began implementing the concept of open innovation using the pentahelix model to realize resilient SMEs. The aim in this study was to determine the relationship and synergy Implementation Effectiveness pentahelix to form a resilient SMEs. 


\section{Research Methods}

This research is a quasi experimental research (Creswell, 2012) using a pretest and posttest. The research was conducted by analyzing the penta helix collaboration at Ratu Manis SMEs. All employees at Ratu Manis SMEs are given a pretest and then the results are compared with the posttest after training on production quality control is carried out . To analyze the results of the pretest and posttest, the data were analyzed using SPSS 20.0 and to determine its effectiveness, the student test (t-test) was carried out.

\subsection{Population and Sample}

The population in this study were all employees of Ratu Manis SMEs, totaling 10 people. The sample used is a total sampling (census) where all members of the population are subject to research.

\subsection{Research Instrument}

The data were taken before and after the implementation of quality control training from the results of the pretest and posttest was carried out by giving questions in the form of essays to all of Ratu Manis SMEs cloud works . The results of the pretest and posttest were tested using paired sample t-test or paired sample $t$ test with valid provisions if the significance $<0.025$. Paired sample t-test or paired sample t test are 2 measurements of information on the same subject towards a certain influence or treatment (Wiyono, 2011).

For the application of appropriate technology compared to the number of defects and the increase in production capacity before and after the application of appropriate technology for thinning pastry dough. Media-based society is measured by the increase in the number of sales of Banyuwangi typical souvenir products.

\section{Result and Discussion}

\subsection{Results of Descriptive Analysis of the Pre-Test and Post-Test Production Quality Control Training}

The results of the descriptive analysis of the pre-test and post-test quality control training using SPSS 20 are shown in table 1 below:

Table 1. Paired Samples Statistics

\begin{tabular}{|ll|r|r|r|c|}
\hline & & Mean & $\mathrm{N}$ & $\begin{array}{c}\text { Std. } \\
\text { Deviation }\end{array}$ & $\begin{array}{c}\text { Std. Error } \\
\text { Mean }\end{array}$ \\
\hline Pair & Pretest & 67.00 & 10 & 12.293 & 3.887 \\
1 & Postest & 79.00 & 10 & 9.661 & 3.055 \\
\hline
\end{tabular}

Table 1 shows the results of the descriptive analysis of quality control training before and after training. Test results indicate the occurrence of $p$ Increased average -rata result of pretest and post- test of 67 into 79.

\subsection{Results of Paired Sample T-Test Analysis}

Increasing the Average Ability of Participants in Statistical Quality Control Training

The results of the analysis of paired sample t-test was used to identify the average value comparison test between the time before and after the training and dali 's quality. The results of the paired sample t- test can be seen in tables 2 and 3 below. 
Table 2. Paired Samples Correlations

\begin{tabular}{|ll|r|r|c|}
\hline & \multicolumn{1}{|c|}{ N } & Correlation & Sig. \\
\hline Pair 1 & $\begin{array}{l}\text { Pretest \& } \\
\text { Postest }\end{array}$ & 10 & .978 & .000 \\
\hline
\end{tabular}

The correlation value between the 2 variables resulted in 0,978 , which means that the relationship is strong and positive. The significance level of the relationship is 0.000 , meaning that it is significant at the 0.05 level.

Table 3. Paired Samples Test

\begin{tabular}{|c|c|c|c|c|c|c|c|c|}
\hline & \multicolumn{5}{|c|}{ Paired Differences } & \multirow[t]{3}{*}{$\bar{t}$} & \multirow[t]{3}{*}{$\overline{\mathrm{df}}$} & \multirow{2}{*}{ Sig. (2-tailed) } \\
\hline & \multirow[b]{2}{*}{ Mean } & \multirow{2}{*}{$\begin{array}{c}\text { Std. } \\
\text { Deviation }\end{array}$} & \multirow{2}{*}{$\begin{array}{l}\text { Std. Error } \\
\text { Mean }\end{array}$} & \multicolumn{2}{|c|}{$\begin{array}{c}95 \% \text { Confidence Interval } \\
\text { of the Difference }\end{array}$} & & & \\
\hline & & & & Lower & Upper & & & \\
\hline $\begin{array}{ll}\text { Pair 1 } & \text { Pretest - } \\
& \text { Postest }\end{array}$ & -12.000 & 3.496 & 1.106 & -14.501 & -9.499 & -10.854 & 9 & .000 \\
\hline
\end{tabular}

Ho: There is no difference in the average test score between before and after training $\mathrm{H} 1$ : There is a difference in the average test score between before and after training If the significance $<0.025$ then Ho is rejected (Wiyono, 2011).

Based on table 3 the significance value is 0.00 , so the significance is $<0.025$, so Ho is rejected, meaning that there is a difference in the average test value before and after quality control training. This means that it can be concluded that employees who receive quality control training have different skill scores from those who do not. Mean - 12, 0 to 00 is negative means that a trend towards increased capacity after training. The average increase was 12,000 .

\subsection{Results of Appropriate Technology Application of thinning machines and dough printing}

To improve the quality and production capacity of the resulting ladrang, appropriate technology for thinning and dough molding machines was applied at Ratu Manis SMEs. With the application of machinery penipis and molding the dough, the production capacity increased from $20 \mathrm{~kg}$ per day to $40 \mathrm{~kg}$ per day.

\subsection{Pentahelix Synergy Model to Form Resilient SMEs in Facing the New Normal during the Covid-19 Pandemic}

The pentahelix model synergy in developing the competitiveness of SMEs is described as follows:

\section{a. University}

The university has a role in higher education, namely in the fields of Education, Research, and Community Service. In this role, the College also plays a major role in the triple helix which is the initial reference of the penta helix concept. In the field of education, the University plays a role in producing knowledge and disseminating knowledge. In the field of research, the University plays a role in the dissemination of research and technology. In the field of community service, the University plays a role in the planning, socialization and dissemination of knowledge (Fitriana, 2016). 
So, universities can play a role in developing the competitiveness of SMEs:

a. In the field of education, it plays a role in helping solve problems faced by SMEs by producing and disseminating new knowledge

b. In the field of research, the role of research is to provide alternative solutions in taking policies about SMEs, to produce innovations to solve problems faced by SMEs, both from the management and technology side. (Arnkil, 2010).

c. In the field of community service, they play a role in participating in the planning process and solving UMKM problems, expert consultants to solve MSME problems, and form business incubators (Fitriana, 2017) and play a role in the transfer of knowledge and technology to business people (Dzisah and Etzkowitz, 2008).

In developing the competitiveness of SMEs, one of the roles of the university is the transfer of appropriate technology for laughing onde-onde printing machines and thinning machines and ladrang dough molders from the University of 17 August 1945 Banyuwangi to Ratu Manis UMKM and quality control training for all employees. This activity is the application of one of the higher education dharma in the field of community service activities (SupRYin et. Al, 2017), based on this to help reduce defective products produced at Ratu Manis UMKM and to expand market reach by obtaining a distribution permit from BPOM.

\section{b. Industry}

Industry plays a role in creating preneurship entrants, products, technology, and as a driver of innovation (Fitriana, 2016). In addition, the industry also plays a role in management training, business coaching, mentoring, and forming communities as a means of sharing ideas (Fitriana, 2016). The role of industry in developing the competitiveness of SMEs is to drive industrial growth so that it can be highly competitive (Izzati and Wilopo, 2018). Industry which is a member of the division that plays a role in producing valueadded goods and services. In this case, SMEs play a role in producing good quality goods and services by using the facilities provided by the University and incubators with funding provided by the government.

According to Agustina and Karyono (2019) Industrial environment as a macro environment plays a role in accelerating the environmental change. The industrial environment refers to the buyers ${ }^{\text {ee }}$ bargaining power. Meanwhile, five factors including the sellers ${ }^{\text {ee }}$ bargaining power, the presence of potential new comers, the existence of substitute goods, and the intensity of corporate competition in an industry are known as competing power (Porter, 1998). Meanwhile, an internal environment consists of structure, culture, and resources (Hunger \& Wheelen, 2012).

\section{c. Government}

The role of government in the triple helix according to Fitriana (2016) is as consumers, investors, and entrepreneurs, as regulators who produce policies related to people, industry, intermediation, institutions, resources and technology, facilitators, catalysts, and provide stimulation, advocate, provide challenges and encouragement to improve business competence.

The government as a stakeholder has regulations and responsibilities in developing business. The role of the government in helping SMEs in Banyuwangi is carried out through the role of the University and business incubators within the university, namely:

a. Through the Business and Technology Incubator program at the innovation directorate of the Ministry of Research and Technology and Higher Education, the government has played a role in helping SMEs to prepare themselves from licensing, product refinement 
to marketing so that in the midst of the COVID-19 pandemic, SMEs have products that are able to compete at the national level even international

b. Through the Community Partnership program at the Directorate of Research and Community Service of the Ministry of Research and Technology and Higher Education, the government has played a role in preparing SMEs to face national and international competition so that even though the number of tourists has decreased and there are no festivals, SMEs can still survive by selling through e-commerce with quality products and already have complete licenses.

\section{d. Media-Based Society}

Public-based media helix, for example television, internet, newspapers, and others, contains information in the form of news, communication and through social networks. The media is the fourth helix of the penta helix (Barth, 2011). Media which is a stakeholder who builds business information and plays a role in promoting business. In this case, the university also plays a role in helping to create publication and promotional content through MSME social media and also through mass media.

\section{e. Community}

Communities are people who have the same interests and relevant business development. One of the food and beverage communities in Banyuwangi Regency is the Food and Beverage Business (UMAMI). UMAMI's role is very big in helping SMEs during the face of COVID-19 where UMAMI members help each other to promote products of UMAMI members, help each other register products on the Bukalapak marketplace, Banyuwangi mall, and other market places. UMAMI members who have expertise in the field of Information and Technology help register and assist other members in marketing through e-commerce. So even though the number of tourists has decreased and there are no festivals, SMEs can still survive with sales through e-commerce.

Synergies Pentahelix SMEs Model to Establish New Normal Resilient in the Face of days the Pandemic Covid-19 contained in Figure 1 below:

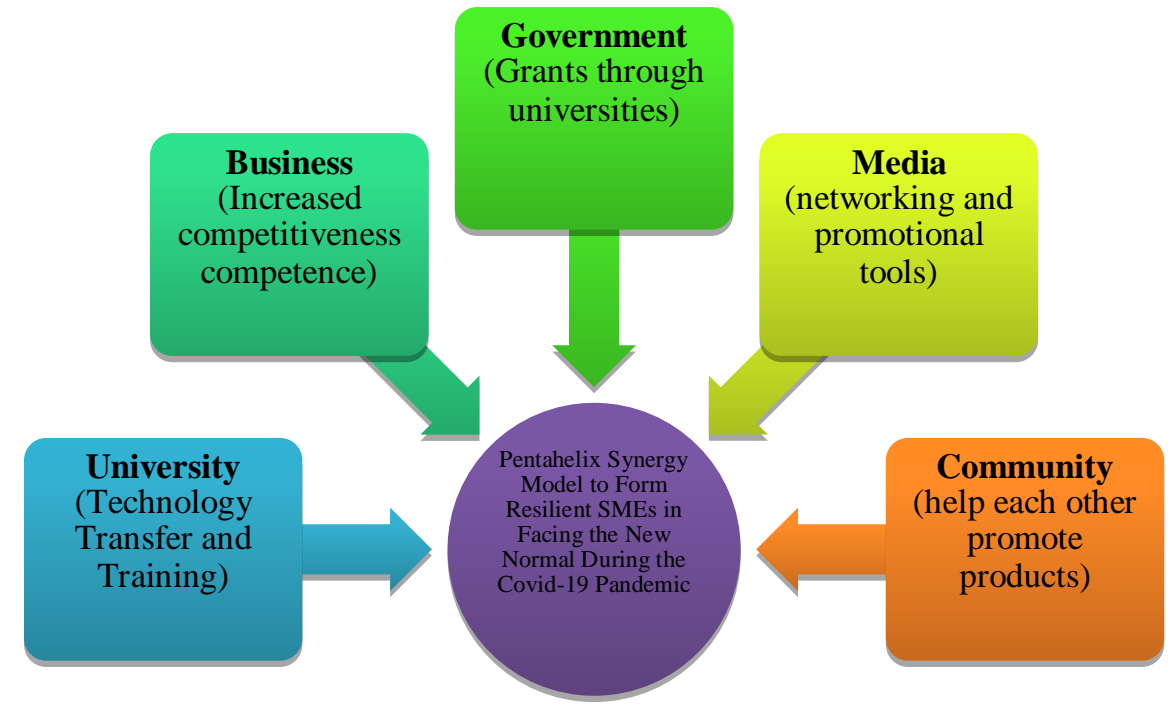

Figure 1. Pentahelix Model Synergy to Form Resilient SMEs in Facing the New Normal during the Covid-19 Pandemic 


\section{Conclusion}

1. To develop the competitiveness of SMEs, the synergy of the University, business, government, media, and the community is needed (penta helix)

2. Synergy SMEs Penta Helix Model to Establish New Normal Resilient in the Face of days the Pandemic Covid-19 can meninges katkan capability human resources, increased right quality, and competitiveness of the products produced by SMEs

\section{References}

Agustina, K., ank Karyono, O. (2019). Developing A Superior Business Strategy Through Industrial Environment And Resources In Manufacturing Smes In West Java Province. Budapest International Research and Critics Institute-Journal (BIRCIJournal). P. 433-442.

Ansari, T.S. (2019). Reminding State Owned Enterprises (BUMN) Management Using the Principle of 'Business Judgment Rule': A Preliminary Note. Budapest International Research and Critics Institute-Journal (BIRCI-Journal). P. 27-38

Arnkil, R. et al. (2010) Exploring Quadruple Helix Outlining user-oriented innovation models Final, Tampere: The CLIQ. Tampereen yliopisto: Tampereen yliopistopaino Oy Juvenes Print. Available at:http://www.arnkildialogues.com/files/testataan.kotisivukone.com/julkaisut/explori ng_quadruple_helix-2010-1.pdf.

Barth, T. D. (2011) 'The idea of a green new deal in a Quintuple Helix Model of knowledge, know-how and innovation', International Journal of Social Ecology and Sustainable Development, 2(1), pp. 1-14. doi: 10.4018/jsesd.2011010101.

Correia, M. S. (2019) 'Sustainability'. International Journal of Strategic Engineering, 2 2938

Creswell, J.W. (2012) Education Research, Planning, Conducting and Evaluating Quantitative and Qualitative Research. 4th edn. Boston: Pearson. (2012) Education Research, Planning, Conducting and Evaluating Quantitative and Qualitative Research. 4th edn. Boston: Pearson.

Dzisah, J. and Etzkowitz, H. (2008) 'Triple helix circulation: the heart of innovation and development', International Journal of Technology Management and Sustainable Development, 7(2), pp. 101-115. doi: 10.1386/ijtm.7.2.101_1.

Fitriana, W. (2016) 'Triple Helix Models for Agro-Tourism Development In West Sumatra', in International Conference on Business, Economics, Socio-culture and Tourism. In Online Proceedings. 1st edn. Semarang: Economics Faculty, pp. 1-556.

Fitriana, W. (2017) 'The Role of Triple Helix Actors for Agro-Tourism Development in West Sumatera', MIMBAR, Jurnal Sosial dan Pembangunan, 33(2), pp. 219-227. doi: 10.29313/mimbar.v33i2.2098.

Hicks, C. C. Levine, A. Agrawal, A. Basurto, X. Breslow, S. J. Carothers, C. Levin, P. S. (2016) 'Engage key social concepts for sustainability'. Science, 352 38-40

Izzati, M. F. and Wilopo (2018) 'Implementasi Triple Helix Dalam Mendorong Pertumbuhan Daya Saing Untuk Menghadapi Masyarakat Ekonomi Asean', Jurnal Administrasi Bisnis, 55(1), pp. 59-68. Available at: http://journal.lembagakita.org/index.php/emt/article/download/20

Leminen, S. Turunen, T. Westerlund, M. (2015) 'The Grey Areas Between Open and Closed in Innovation Networks. Technology Innovation Management Review', 5 618 
Leydesdorff, L. Ivanova, I. (2016) "Open innovation" and "triple helix" models of innovation: can synergy innovation systems be measured? Journal of Open Innovation: Technology, Market, and Complexity, 2

Mathur, K. Berwa, A. (2017) 'Sustainable competitiveness: redefining the future with technology and innovation. Journal of Sustainable Finance \& Investment', 7290 306

Sturesson. Elof; Lindmark, Adam and Nilsson Roos. Markus, (2009). "Collaboration for Innovation - A Study in the Öresund Region", Sweden: Lund University Libraries.

Suprihatin, E. Ferawati, I. W, Susanti, H. D. (2018) 'PKM Kelompok UMKM Kue Kering di Kabupaten Banyuwangi', Seminar Nasional Untag Surabaya ISBN 90786025069987, 1(1), pp. 153-167. Available at: http://jurnal.untagsby.ac.id/index.php/semnasuntag/article/view/1666

Vanhaverbeke, W. (2013) 'Rethinking Open Innovation Beyond the Innovation Funnel. Technology Innovation Management Review', 3 6-10

Vyakina, I. V. (2018) 'Social and environmental aspects of economic security as part of the sustainable development concept'. National Interests: Priorities and Security, 14 2259-2276

Wiyono, G. (2011) Merancang penelitian bisnis dengan alat analisis SPSS 17.0 \& SmartPLS 2.0. Pertama. Yogyakarta: UPP STIM YKPN 